\title{
Manufacture Strategy Stages and Strategy-as-Practice Phases
}

\author{
Estágios da Estratégia de Manufatura e Fases da \\ Estratégia na Prática
}

\section{Lígia Maria Heinzmann}

Docente do Departamento de Administração da Universidade Federal de Mato Grosso - Cuiabá - MT - Brasil.

E-mail: ligiamhz@hotmail.com

\section{Rosália Aldraci Barbosa Lavarda}

Docente do Instituto Federal de Educação, Ciência e Tecnologia Catarinense - Blumenau - SC - Brasil. E-mail: rosalia.lavarda@ifc.edu.br

\section{Denise Del Prá Netto Machado}

Docente do Programa de Pós-Graduação em Ciências Contábeis e Administração da Universidade Regional de Blumenau - Blumenau -SC - Brasil.E-mail: delpra@furb.br

\section{Nelson Hein}

Docente do Programa de Pó-Graduação em Ciências Contábeis e Administração da Universidade Regional de Blumenau - Blumenau - SC - Brasil. E-mail: hein@furb.br

\section{Abstract}

These studies aimed to analyze the stage of the manufacture strategies in the units of the organization, in agreement with the adaptation of the Manufacture Strategy Model of Bates et al (1995) and the phases that characterizes the strategy-as-practice. This sample composed by 22 leaderships of the units (Goiás/ GO), Rio Grande do Sul (RS) and São Paulo (SP). The research used a diffuse genetic model and the Software MATLAB ${ }^{\circledR}$ 5.0. Regarding the manufactures strategies stage, Goiás meets in the stage 3 (develops basis to business strategy) - and some characteristics belonging to stage 4 . The Unit RS meets in stage 4, with some characteristics of stage 3. São Paulo meets in stage 3 , with some characteristics still of stage 2 . The phase Production Strategy Force appears significantly in the three Units analyzed. Concerning the phases that characterize the strategy-as-practice, the Units RS and Goiás present similarity in most phases.

Key words: Organization. Manufacture strategy. Strategy-as-practice. Strategizing. Diffuse Genetic Model.

\section{Resumo}

O objetivo deste estudo foi analisar o estágio das estratégias de manufatura nas unidades da organização de acordo com adaptação do Modelo de Estratégia de Manufatura de Bates et al. (1995) e as fases que caracterizam a estratégia na prática. A amostra foi composta por 22 chefias das unidades (Goiás, Rio Grande do Sul (RS) e São Paulo). Utilizou-se um modelo genético difuso e o Software MATLAB ${ }^{\circledR}$ 5.0. Referente ao estágio das estratégias de manufatura, Goiás encontra-se no Estágio 3 (desenvolve suporte para sua estratégia de negócio) também atendendo a características do Estágio 4 (persegue vantagem competitiva, a partir da manufatura, e cria um padrão a ser seguido pelas demais empresas). A Unidade RS encontra-se no Estágio 4, com algumas características ainda do Estágio 3. São Paulo encontra-se no Estágio 3, com algumas características ainda do Estágio 2. A Fase da Força da Estratégia de Produção destaca-se nas três Unidades.

Palavras-chave: Organização. Estratégia de Manufatura. Estratégia na Prática. Strategizing. Modelo Genético Difuso. 


\section{INTRODUCTION}

The manufacturing strategy translated into the production function and aligned to organizational politics is an action that helps the organization to achieve competitive advantage, important factor of organizational survival. (BATES et al., 1995)

The authors Hayes and Wheelwright (1984) developed a classification of four stages, in which the manufacture of an organization is found in relation to the competitive business strategy adopted. In this context, this paper is to analyze at what stage of the manufacturing strategy drives the organization are in accordance with the adjustment of the Manufacturing Strategy Model of Bates et al (1995). In a second step, this also aims to analyze the phases present activities that characterize the strategy-as-practice.

For this analysis were prepared two questions: 1) At what stage of the manufacturing strategy business units are adapted according to the model of Bates et al. (1995)? 2) What are the phases that have activities that characterize the strategy-as-practice? From the perspective of designing strategies below, which are the stages involving the manufacture and operation phases of the practice, it is expected that this work will help the organization in recognition of the degree to which it stands. In this context, the results may serve as a benchmark for the design of other actions that could help the organization, both in manufacturing management and in developing and implementing their strategies. Also, it is expected as academic contribution, to show the possibility of applying the Model Bates et al. (1995), even in an adapted way.

In the introduction, this article presents four sections. The second presents the literature review, which seeks to highlight approaches to strategies, the main references on strategies and manufacturing strategies in practice. The method and research techniques are exposed in the third section. The fourth section presents the analysis of results and the fifth and final section presents the final considerations.

\section{Contextualization of Manufacturing Strategy}

The manufacturing strategy basically consists of a set of plans and programs developed and implemented so that the manufacturing area helps to increase the competitiveness of the company. The manufacturing strategy is the result of decisions that over time, enables a business unit to find a structure, an infrastructure of production and a set of specific skills. (HAYES; WHEELWRIGHT, 1984)

The manufacturing function is to provide consistency between the political capacity and competitive advantage by translating business strategy into a set of decisions involving people, equipment, resources, time and management. In this sense is defined manufacturing strategy as "[...] design for the manufacturing function that shapes the acquisition, development of manufacturing capabilities over time" (BATES et al., 1995 , p. 1.566). The strategy is used to coordinate decision-making including selection of manufacturing technology, suppliers, manufacturing planning and control systems, labor and quality practices.

Once that is formulated the manufacturing strategy should be communicated to the staff of the factory, so that they understand how the goals, policies and objectives are derived from the manufacturing strategy, and can use the strategy to guide decision-making.

The concept of manufacturing strategy "[...] is a natural extension of the concept of corporate strategy" (HAYES; SCHMENNER apud UYTERHOEN, 1986, p. 33). Manufacturing works best when its facilities, technology and policies are consistent with recognized priorities of business strategy. The definition of manufacturing strategy

[...] it is the set of tasks and coordinated decisions that need to be taken to meet the demands of the competitive objectives of the company. A manufacturing strategy of a company should define its technology, human resources, organization, capabilities, interfaces and infrastructure. It is the last link that connects the global business strategy of an organization to the actions of their individual resources and, as such, should lead directly to an understanding of competitive strategy. (SLACK, 2002, p. 29) 
Accordingly, "[...] the fundamental aspects of competitiveness are clearly within the field of operation of the function of manufacturing. It has a direct influence on the competitive aspects of performance" (SLACK, 2002, p. 19). The manufacture determines the ability of the company to offer products at prices that make it possible to compete with competitors and have a higher profit margin.

The manufacturing strategy aims to

[...] ensure that the processes of production and delivery of customer value are aligned with the strategic intent of the company regarding the financial results, the markets it serves and adapted to the environment in which it operates. (CORREA; CORREA, 2004, p. 56)

For Slack (2002, p. 195):

[...] a believable manufacturing strategy reinforces the centrality of the concept of competitiveness in the culture of the organization. It does this by focusing on links between the company's strategy as a whole, the objectives of manufacturing, the various tasks of manufacturing and individual features of the manufacturing system. A manufacturing strategy should effectively bring the concept and the feeling of "competitiveness" to the plant - the true heart of the company.

When the author refers to the manufacture to be credible, it is in the sense to be performed. Because a strategy that is not perceived as possible of achievement will be supported by the company.

The strategy of producing each unit contributes to the strategic goals of the next higher level. But in addition to helping the top level in the hierarchy to achieve its strategic objectives, the production strategy must consider the needs of its customers and internal suppliers. (SLACK et al., 1997, p. 91)

In this sense, means a manufacturing strategy has the purpose to contribute directly to strategic goals of higher level in the hierarchy and help other areas of the company to make its own contribution to the strategy.

A well-aligned and implemented manufacturing strategy uses the following dimensions:

a) a process of formal strategic planning, which involves the management of factory; b) communication strategy for the staff of the factory;

c) long-term strategy;

d) strong or influential within the factory;

e) connection of manufacturing strategy with business strategy;

f) business strategy that is built on the production capacity (BATES et al., 1995, p. 1.566)

A manufacturing strategy can be well aligned and implemented, if it displays most or all dimensions. To achieve a greater involvement, the companies emphasize the development of strategic and operational plans for the administration line. "Some governments try to involve the managers of the lowest level in more prevalent in the creation of long-term plans". (BANKS; WHEELWRIGHT apud DRUCKER, 1986, p. 69).

In the view of Paiva et al. (2004, p. 15)

$[\ldots]$ it should be the operations manager to understand and participate in the company's strategic choices, ie choose which competitive criteria could focus its operational resources to support the competitive strategy of the company, and depending on your dedication and success over time, transform own operations into a source of competitive advantage.

There are several definitions of manufacturing strategy, and there is one that is widely accepted. There is agreement that this definition must match the objectives of the company or business unit, to achieve the goals of the area of operations, seek a competitive advantage and focus on a consistent pattern of decisions regarding the operations. (PAIVA et al., 2004)

\subsection{Stages of Manufacturing Strategy}

Authors Hayes and Wheelwright (1984) developed a classification of four stages, in which the manufacture of a given firm is in relation to the competitive business strategy adopted, the stages are:

a) Stage 1 - minimize the negative aspects of potential manufacturing (internally neutral).

b) Stage 2 - reaches parity with its competitors (externally neutral).

c) Stage 3 - developing support for its business strategy (support internal). 
d) Stage 4 - chasing a basis of competitive advantage from the manufacturing and creates a standard that will be sought by other companies. (HAYES; WHEELWRIGHT, 1984, p. 396)

In Stage 1 - "the production is kept flexible and reactive" (HAYES; WHEELWRIGHT, 1984, p. 396). There is greater concern for the competitors and whether they are direct competitors or not. At this stage, product development is minimal and management believes that operating without major disruptions, they will be getting acceptable margins, and the main goal is to keep costs low.

In this context, employees have little technical training, and functional areas have little integration between them. They are also considered less significant strategic issues such as human resources policy, planning, performance indicators and internal process improvements.

In Stage 2 - the company adopts the usual practices from the category of industry to which it belongs has internal plans and offers products similar to those of other companies. Work systems tend to be closer to its competitors.

With respect to operations, Hayes and Wheelwright (1984) consider that to achieve a position of neutrality, seeking thus to par with its competitors and a state of operation without interruption. Seeking external neutrality (relative to competitors) and internal neutrality (production without major problems) in relation to the size of manufacturing.

In Stage 3 - the managers of the highest level have a clear vision of what is valued by the client and seek actions in order to develop that value the customer perceives. The operations performed in different functional areas are mutually consistent, and these operations must also guide the tactics and leadership in implementing the strategy you want. At this stage employees are encouraged to take initiatives and make choices between different procedures. The challenge for the company is to make the manufacturing supports the business strategy of the company being considered as a manufacturing power base of the company's competitive position. (HAYES; WHEELWRIGHT, 1984)

In this sense, "manufacturing is of internal support, ie, is related and gives support to the business strategy of the company" (HAYES; WHEELWRIGHT, 1984, p. 396). This positioning occurs through: plan- ning decisions (to ensure that they are consistent with the strategy of the business); recognition of significant policy issues related to manufacturing, internal consistency in decisions relating to manufacturing, and formulating a clear strategy for operations for orientation activities for a given period of time. (HAYES; WHEELWRIGHT, 1984)

In Stage 4 - the company needs to develop capabilities and commitments internally to transform its operations. Conditions to favor the employees to achieve new standards of performance. Companies should be proactive and identify new business opportunities. The challenge of this stage is to maintain superior performance in all areas that make up the company. The area of operations will take an important role in the company's competitive strategy. (HAYES; WHEELWRIGHT, 1984)

The main characteristics of the companies at this stage are:

1) anticipation of the potential of new technologies and practices in the area of operations, acquiring technical competence before other companies;

2) credibility and influence in the area of operations, in order to reach that full potential;

3) long-term planning in the area of operations is considered of high importance to achieve strategic objectives of the company. (HAYES; WHEELWRIGHT, 1984, p. 399)

For the area of operations to make it a strategic force, it is necessary to develop integrated business strategy, manufacturing and other functional areas. The stages of manufacturing strategy consist of phases that have activities that characterize the strategy-as-practice. The construct of the instrument of data collection (topic 3.2.1) presents the items that involve these activities. That is, the more opportunities that the strategy-as-practice are present in the organization, the more they contribute to the advancement in the stages of manufacturing strategy.

\subsection{Strategies-as-Practice}

Considering the perspective of strategy-as-practice (JARZABKOWSKI, 2003, 2008; JARZABKOWSKI; FENTON, 2006; JARZABKOWSKI; BALOGUN; SEIDL, 2007; JARZABKOWSKI; WHITTINGTON, 2007, 
2008; JARZABKOWSKI; SEIDL, 2008) it appears that the literature remains dominated by concepts from the strategy considered as a process of formulating a separate top-down implementation, with focus on senior management and its process of decision making.

However, a new perspective, a new approach is gaining authority and is being supported by empirical research (JARZABKOWSKI; SILLINCE, 2006; REGNER, 2008; ROULEAU, 2005). This perspective has been broadened by research conducted by Jarzabkowski (2003, 2005, 2006, 2007 and 2008).

Important conceptual guidelines are offered trough studies by Jarzabkowski, Balogun and Seidl (2007) reporting different aspects of strategy-as-practice, which is used in this study to review and synthesize this kind of understanding of the strategy. Thus, from the perspective of Jarzabkowski (2003) strategy is defined as a specific social activity, comprises actions, interactions and negotiations of multiple actors and specific practices that are designed, planned to hold such activities.

This is a broad definition as it covers all types of social activity; it is difficult to determine "what activity is not strategic" (JARZABKOWSKI; BALOGUN; SEIDL, 2007 , p. 7). A proposal to deal with this problem is to focus on those activities designed as strategic practices. The strategy is a particular type of activity that is linked to particular practices, such as strategic planning, annual budget meetings and to define the strategy. The main strategic practices are identified as formal operational procedures involved in direction setting, application of resources, monitoring and control.

In theory the practical activity is posited as essential for the analysis of the interaction between actors and collective structures. The ability to change in practice results from the interaction between actors and practical activities. (JARZABKOWSKI, 2003, p. 28)

Increasingly, the strategy "[...] is also seen as a practice strategy is something more to do" (WHITTINGTON, 2006, p. 613). The essential idea of the perspective of the Strategy is more than just a property of organizations; "it's something people do, with things coming out, and within organizations, and with effects that affect the entire society" (WHITTINGTON, 2006, p. 627). Approaching strategy "[...] as something people do, therefore, adds an extra dimension to the traditional discipline of particular concern to provide organizations with winning strategies and efficient processes". (WHITTINGTON, 2006, p. 629)

Regner (2008) examines how a practical approach to strategy can complement the work on dynamic capabilities and support the development a dynamic strategy. While the dynamic capabilities emphasize work skills in organizational strategy and practical approach has important features that can help to advance the analysis of processes and activities that support these capabilities (REGNER, 2008, p. 567). A dynamic strategy needs to go beyond simple correlations between variables and to explain the mechanisms of how certain conditions interact to produce certain organizational assets. (REGNER, 2008)

The strategy, as a practical approach, explicitly recognizes that a diverse set of actors may be involved in developing new strategies and contribute to the accumulation of organizational assets, and that middle managers can be highly influential in this process. (BALOGUN; JOHNSON, 2004; FLOYD; WOOLDRIDGE, 2000; REGNER, 2008, p. 575)

The strategy and practical approach has the power to investigate not only the capabilities of senior management in relation to strategic change, but the ability of various actors and groups that are heterogeneous internal and external to a company or organization. (REGNER, 2008, p. 575)

\section{Methods and Techniques of Research}

The research design used as a reference Richardson et al. (1999) and Hair Jr. et al. (2005) for their classification. The research method adopted is quantitative, as Richardson et al. (1999, p. 70), "[...] the quantitative method, as its name implies, is characterized by the use of quantification in both methods of data collection, as to their treatment by means of statistical techniques, from the simplest to the most complex". In this study, the objective requires the use of this method. Using a classifier hybrid system based on metaheuristic genetic algorithms of Holland (1975) and Zadeh's fuzzy math (1965), to identify at what stage of the manufacturing strategy business units are located.

Under the quantitative approach, this work falls as descriptive, "[...] the descriptive plans are generally structured and specifically designed to measure the 
characteristics described in a research question" (HAIR Jr. et al., 2005, p. 86). This view is through the adjustment of the Model of Bates et al. (1995), which seeks to analyze at what stage of the strategy of manufacturing units are located and what are the stages that present opportunities that the strategy-as-practice. The study presents cross-sectional data collected in March 2009.

\subsection{Characterization of the Organization - Population and Sample}

The organization chosen to affect the instrument has the head office located in São Paulo, has two branches, one in Rio Grande do Sul (RS) and the state of Goiás (GO). It was selected because of its large size, has more than one unit, thus enabling a comparison between them on the stage of manufacturing strategy to meet and also the openness and accessibility to data.

The origin of the organization date of 1955, and was acquired by the current controlling group in 1963. In 1965 changes its name to that currently use, expanding its activities and incorporating the other processes already in production. In 1980 it began its geographic diversification, with the acquisition of a unit in southern Brazil. In 1990 its targeting exports are Uruguay and Argentina. In 1992 it established the third unit in the Central West region, given the growing demand in that region.

In 2005 begins to be part of a major international association. In 2006 looking to the future in order to widen its property located in Southeastern Brazil, from where the patented products to the world. The philosophy includes a commitment to long-term shareholders, employees, customers and suppliers. The company ranks third in the sector by consumption of raw materials, and the first in its segment. The country has about 50 (fifty) companies that produce the same product, some of them very small and regional. Approximately 10 (ten) companies are medium to large businesses, and the leader holds around 15\% (fifteen percent) of the total, when measured in consumption of basic raw material for the production process. The 10 (ten) largest companies together represent around $75 \%$ (seventy five percent) of the market.

The company seeks technology leadership as a tool to support its strategy of product differentiation, in which case means a constant search for innova- tions that add value to their products. The company's stock is fully national, ranked as the third company in the sector, employs 991 (nine hundred ninety-one) employees in its 3 (three) units, São Paulo, Goiás and Rio Grande do Sul.

\subsubsection{Respondents}

Respondents were managers, managers and chiefs of the three manufacturing units, as shown in Table 1.

Table 1: Population and study sample

\begin{tabular}{|c|c|c|c|}
\hline Units & Managements & Respondents & \% PeR Unit \\
\hline SP & 34 & 10 & $29.4 \%$ \\
\hline GO & 8 & 03 & $37.5 \%$ \\
\hline RS & 22 & 09 & $40.9 \%$ \\
\hline Total & 64 & 22 & \\
\hline
\end{tabular}

Source: Research data

\subsection{Instrument for Data Collection}

For data collection was developed to adapt the Model of Manufacturing Strategy Bates et al. (1995). This Model, originally introduced Scales Manufacturing Strategy and Organizational Culture Scales (BATES et al., 1995). For the present research used the following scales: Manufacturing Strategy, which are divided into eight Phases, four phases of the strategic, long-term orientation, strength of manufacturing strategy, formal strategic planning, and communication strategy. The instrument was used Likert Scale of 1 to 5 points, which presented the response options "strongly disagree", "partially disagree", "I have not formed an opinion", "partially agree" and "strongly agree".

\subsubsection{Construct of the instrument of data collection}

It presents the construct of research with respect to the instrument for data collection, according to Silveira et al. (2009, p. 76) shows the construct "[...] the specific objectives of research faced with the variables or terms defined in the research and the corresponding items in instruments for collecting data, when in questionnaires and structured interviews". 
Figure 1 shows the Construct. In the phases 1 to 4 indicate at what stage of the manufacturing strategy units are and also have items that involve activities that characterize the strategy-as-practice. In turn, the phases 5 to 8 are related to items that involve activities that characterize the strategy-as-practice.

\begin{tabular}{|c|c|c|}
\hline Specific Objectives of the Research & Phases of the Instrument & Items Phases of the InStrument for data Collection \\
\hline $\begin{array}{l}\text { a) analyze the stage of manufacturing } \\
\text { strategy in which the company is. } \\
\text { b) analyze what phases present activities } \\
\text { that characterize the strategy-as-practice. }\end{array}$ & $\begin{array}{l}\text { Phase } 1 \text { - Strategic Role } \\
\text { Phase } 2 \text { - Strategic Role } \\
\text { Phase } 3 \text { - Strategic Role } \\
\text { Phase } 4 \text { - Strategic Role }\end{array}$ & $\begin{array}{l}\text { 1.1Control Systems; } \\
\text { 1.2 Flexibility of production; } \\
\text { 1.3 Problem solving; } \\
\text { 1.4 Performs short-term; } \\
\text { 1.5 Consultants external; } \\
\text { 2.1 Misleading industrial; } \\
\text { 2.2 Dependence on suppliers; } \\
\text { 2.3 Wages industry standard; } \\
\text { 2.4 Planning based on repetition of tasks; } \\
\text { 2.5 Capital invested in production; } \\
\text { 3.1 Production systematic; } \\
\text { 3.2 Was in production strategy; } \\
\text { 3.3 Business strategy involving the production; } \\
\text { 3.4 Investments in production as a business strategy; } \\
\text { 3.5 Production in line with strategy; } \\
\text { 4.1 Development of own equipment; } \\
\text { 4.2 Production involved with } \\
\text { decisions; } \\
\text { 4.3 Areas included; } \\
\text { 4.4 Long-term programs; } \\
\text { 4.5 Anticipation of new production processes; }\end{array}$ \\
\hline \multirow{4}{*}{$\begin{array}{l}\text { b) analyze what phases present activities } \\
\text { that characterize the strategy-as-practice. }\end{array}$} & $\begin{array}{l}\text { Phase } 5 \text { - Long-Term } \\
\text { Orientation }\end{array}$ & $\begin{array}{l}\text { 5.1 Financial Targets; } \\
\text { 5.2 Emphasis on goals; } \\
\text { 5.3 Financial performance of short term; } \\
\text { 5.4 Long-term orientation; } \\
\text { 5.5 Loss impact decisions; }\end{array}$ \\
\hline & $\begin{array}{l}\text { Phase } 6 \text { - Strength of Stra- } \\
\text { tegy Production }\end{array}$ & $\begin{array}{l}\text { 6.1 Monitoring of performance; } \\
\text { 6.2 Production strategy developed; } \\
\text { 6.3 Production with focus; } \\
\text { 6.4 Production with competitive strength; }\end{array}$ \\
\hline & $\begin{array}{l}\text { Stage } 7 \text { - Formal Strategic } \\
\text { of Planning }\end{array}$ & $\begin{array}{l}\text { 7.1 Planning Strategy formal; } \\
\text { 7.2 Planning prepared by the summit; }\end{array}$ \\
\hline & $\begin{array}{l}\text { Stage } 8 \text { - Communication } \\
\text { Strategy }\end{array}$ & $\begin{array}{l}\text { 8.1 Communication strategy to all; } \\
\text { 8.2 Communication strategy managers; } \\
\text { 8.3 People familiar with the planning; } \\
\text { 8.4 Understanding the long-term strategy. }\end{array}$ \\
\hline
\end{tabular}

Figure 1: Construct in relation to the instrument of data collection Source: Adapted by Bates et al. (1995)

In the topic following the statistical procedures are presented for data analysis.

\subsection{Procedures for Statistical Data Analysis}

To identify and analyze at what stage the company's units are the data were processed by statistical techniques, we used a hybrid classifier system based on metaheuristic genetic algorithms of Holland (1975) and Zadeh's fuzzy math (1965). The research that has availed itself of a genetic model to diffuse the first four stages of Model Bates et al. (1995). The genetic model diffuse (artificial) served as an aid to the classification of the responses of managers.

For Hein (1995) theory of fuzzy sets or fuzzy logic, distinguishes itself by working with approximate reasoning in order to achieve inferences, to allow it to better fit the natural language, recapturing the meaning of vague terms or ambiguous, as in classical theory as fuzzy predicates. Thus, one element does not neces- 
sarily belong to a group, without a continuous degree of membership, ie, where the passage of relevance for non-membership is gradual rather than abrupt (ZIMMERMANN, 1991 apud HEIN; NOVELLO, 2006, p. 6). This phase of the research used the MATLAB $\circledR$ software version 5.0. The responses were converted into a scheme with chromosome ploidy level 5 (pentaploid - chromosome scheme with 5 levels). The responses were converted to alleles (one allele is a value for a gene). The responses were fuzzyfied according to the following five schemes (Figure 2).

\begin{tabular}{|c|c|c|c|c|c|}
\hline $\begin{array}{l}\text { Scores chargeable to the } \\
\text { characteristics }\end{array}$ & 1 & 2 & 3 & 4 & 5 \\
\hline $\begin{array}{l}\text { Score assigned by the } \\
\text { respondent }\end{array}$ & $X$ & & & & \\
\hline $\begin{array}{l}\text { Score fuzzyfied by the } \\
\text { system }\end{array}$ & 1 & 0 & 0 & 0 & 0 \\
\hline $\begin{array}{l}\text { Scores chargeable to the } \\
\text { characteristics }\end{array}$ & 1 & 2 & 3 & 4 & 5 \\
\hline $\begin{array}{l}\text { Score assigned by the } \\
\text { respondent }\end{array}$ & & $X$ & & & \\
\hline $\begin{array}{l}\text { Score fuzzyfied by the } \\
\text { system }\end{array}$ & 1 & 2 & 1 & 0 & 0 \\
\hline $\begin{array}{l}\text { Scores chargeable to the } \\
\text { characteristics }\end{array}$ & 1 & 2 & 3 & 4 & 5 \\
\hline $\begin{array}{l}\text { Score assigned by } \\
\text { respondent }\end{array}$ & & & $X$ & & \\
\hline $\begin{array}{l}\text { Score fuzzyfied by the } \\
\text { system }\end{array}$ & 1 & 2 & 3 & 2 & 1 \\
\hline $\begin{array}{l}\text { Scores chargeable to the } \\
\text { characteristics }\end{array}$ & 1 & 2 & 3 & 4 & 5 \\
\hline $\begin{array}{l}\text { Score assigned by the } \\
\text { respondent }\end{array}$ & & & & $\mathrm{X}$ & \\
\hline $\begin{array}{l}\text { Score fuzzyfied by the } \\
\text { system }\end{array}$ & 1 & 2 & 3 & 4 & 3 \\
\hline $\begin{array}{l}\text { Scores chargeable to the } \\
\text { characteristics }\end{array}$ & 1 & 2 & 3 & 4 & 5 \\
\hline $\begin{array}{l}\text { Score assigned by the } \\
\text { respondent }\end{array}$ & & & & & $X$ \\
\hline $\begin{array}{l}\text { Score fuzzyfied by the } \\
\text { system }\end{array}$ & 1 & 2 & 3 & 4 & 5 \\
\hline
\end{tabular}

Figure 2: Answers fuzzyfied according to the five schemes Source: Research data
The fuzzyfication was drafted to distribute lateral part of the latent value of the allele marked by the respondent. The variation of the lateral distribution followed the reduction in one unit alleles, depending on the distance at which the gene is separated from another chromosome. The respondent noted that a gene on chromosome 1 the value is null allele, on chromosome 2 allele value is 1 , on chromosome 3 the value of the allele on chromosome 2 and 4 allele value is 3 .

It is presented the genetic system of a respondent to the unit of Rio Grande do Sul (phase 1.1 to phase 4.5) before and after fuzzyfication in Figures 3 and 4.

For each phase was elaborated a genetic diffuse scheme (hybrid classifier system). Getting the model (phases in their pure state) was given by assigning a maximum score of the items in phases 1 to 4 by the Construct the instrument of data collection (Figure 1).

Figure 5 shows the Stage 1 in its pure state, ranging from phase 1.1 to phase 4.5 .

After the fuzzyfication of the data was calculated the analysis of distances, we used the metric to calculate the distances chromosomic given by the expression:

$$
\begin{aligned}
& \mathrm{d}\left(e_{\mathrm{i}}, e_{\mathrm{j}}\right)=\left[\operatorname{Max}\left(e \mathrm{ig}\left(\left(e_{\mathrm{i}-} e_{\mathrm{j}}\right)^{*}\left(e_{\mathrm{i}-} e_{\mathrm{j}}\right)^{\mathrm{t}}\right)\right)\right]^{1 / 2}, \text { where: } \\
& \mathrm{d}=\text { distance } \\
& e_{\mathrm{i}}=\text { alleles diffuse } \\
& e_{\mathrm{j}}=\text { alleles reference } \\
& \mathrm{Max}=\text { Matrix } \\
& \text { eig }=\text { eigenvalues (auto-values) } \\
& \mathrm{t}=\text { transposed }
\end{aligned}
$$

The matrix $e_{i}$ will be loaded with alleles diffuse of the respondents and the matrix $e_{j}$ is the reference, ie the pure phase. The shortest distance will point to that stage belongs to respond to a greater degree. Each response can be written in the form of a matrix of 5 lines and 20 columns, that $\left(e_{\mathrm{i}}, e_{\mathrm{j}}\right)$ will give origin to a new matrix $5 \mathrm{x}$ 20. Multiplying this matrix by its transpose $\left(e_{\mathrm{i}-} e_{\mathrm{j}}\right)^{\mathrm{t}}$, one arrives at a homogeneous matrix $5 \times 5$, which the sum of the elements from its trace is equal to the sum of its eigenvalues, which in the case are 5 values. Through the above we proceed to the analysis of results. 


\begin{tabular}{|c|c|c|c|c|c|c|c|c|c|c|c|c|c|c|c|c|c|c|c|}
\hline F11 & F12 & F13 & F14 & F15 & F21 & F22 & F23 & F24 & F25 & F31 & F32 & F33 & F34 & F35 & F41 & F42 & F43 & F44 & F45 \\
\hline 5 & & 5 & & & 5 & & 5 & & & & & 5 & & & & & & 5 & \\
\hline & & & 4 & 4 & & & & & 4 & 4 & 4 & & 4 & 4 & & 4 & 4 & & 4 \\
\hline & & & & & & & & 3 & & & & & & & & & & & \\
\hline & 2 & & & & & 2 & & & & & & & & & 2 & & & & \\
\hline & & & & & & & & & & & & & & & & & & & \\
\hline
\end{tabular}

Figure 3: Interpretation of a gene respondent Unit of Rio Grande do Sul before the fuzzyfication data.

Source: Research Data

\begin{tabular}{|c|c|c|c|c|c|c|c|c|c|c|c|c|c|c|c|c|c|c|c|c|c|}
\hline F11 & F12 & F13 & F14 & F15 & F21 & F22 & F23 & F24 & F25 & F31 & F32 & F33 & F34 & F35 & F41 & F42 & F43 & F44 & F45 \\
\hline 5 & 0 & 5 & 3 & 3 & 5 & 0 & 5 & 1 & 3 & 3 & 3 & 5 & 3 & 3 & 0 & 3 & 3 & 5 & 3 \\
\hline 4 & 0 & 4 & 4 & 4 & 4 & 0 & 4 & 2 & 4 & 4 & 4 & 4 & 4 & 4 & 0 & 4 & 4 & 4 & 4 \\
\hline 3 & 1 & 3 & 3 & 3 & 3 & 1 & 3 & 3 & 3 & 3 & 3 & 3 & 3 & 3 & 1 & 3 & 3 & 3 & 3 \\
\hline 2 & 2 & 2 & 2 & 2 & 2 & 2 & 2 & 2 & 2 & 2 & 2 & 2 & 2 & 2 & 2 & 2 & 2 & 2 & 2 \\
\hline 1 & 1 & 1 & 1 & 1 & 1 & 1 & 1 & 1 & 1 & 1 & 1 & 1 & 1 & 1 & 1 & 1 & 1 & 1 & 1 \\
\hline
\end{tabular}

Figure 4: Data fuzzyfied in Figure 3

Source: Research Data.

\begin{tabular}{|c|c|c|c|c|c|c|c|c|c|c|c|c|c|c|c|c|c|c|c|c|c|}
\hline F11 & F12 & F13 & F14 & F15 & F21 & F22 & F23 & F24 & F25 & F31 & F32 & F33 & F34 & F35 & F41 & F42 & F43 & F44 & F45 \\
\hline 5 & 5 & 5 & 5 & 5 & 3 & 3 & 3 & 3 & 3 & 1 & 1 & 1 & 1 & 1 & 0 & 0 & 0 & 0 & 0 \\
\hline 4 & 4 & 4 & 4 & 4 & 4 & 4 & 4 & 4 & 4 & 2 & 2 & 2 & 2 & 2 & 0 & 0 & 0 & 0 & 0 \\
\hline 3 & 3 & 3 & 3 & 3 & 3 & 3 & 3 & 3 & 3 & 3 & 3 & 3 & 3 & 3 & 1 & 1 & 1 & 1 & 1 \\
\hline 2 & 2 & 2 & 2 & 2 & 2 & 2 & 2 & 2 & 2 & 2 & 2 & 2 & 2 & 2 & 2 & 2 & 2 & 2 & 2 \\
\hline 1 & 1 & 1 & 1 & 1 & 1 & 1 & 1 & 1 & 1 & 1 & 1 & 1 & 1 & 1 & 1 & 1 & 1 & 1 & 1 \\
\hline
\end{tabular}

Figure 5: Scheme of genetic system to Stage 1 in its pure state - fuzzyfied Source: Research data 


\section{Analyses of Results}

As shown in the detailed statistical procedures are that the distance chromosome was used as the square root of the largest eigenvalue found. The matrix of distances between the phases (genetically pure) is presented by Unit in Figure 6.

\begin{tabular}{|c|c|c|c|c|}
\hline \multicolumn{5}{|c|}{ Goiás } \\
\hline ManAGEMENTS & Stage 1 & StAge 2 & Stage 3 & Stage 4 \\
\hline 01 & 20.54 & 17.7 & 15.97 & 15.61 \\
\hline 02 & 20.03 & 17.27 & 16.91 & 17.44 \\
\hline 03 & 17.06 & 13.75 & 12.53 & 12.74 \\
\hline \multicolumn{5}{|c|}{ Rio Grande do Sul } \\
\hline ManAGEMENTS & Stage 1 & StAGE 2 & Stage 3 & Stage 4 \\
\hline 01 & 16.21 & 12.82 & 12.41 & 13.37 \\
\hline 02 & 18.4 & 13.97 & 11.47 & 11.06 \\
\hline 03 & 19.15 & 13.4 & 10.37 & 10.23 \\
\hline 04 & 16 & 11.76 & 11.43 & 12.44 \\
\hline 05 & 20.58 & 15.04 & 12.33 & 12.24 \\
\hline 06 & 17.78 & 12.37 & 9.2 & 8.61 \\
\hline 07 & 21.2 & 16.69 & 14.11 & 13.84 \\
\hline 08 & 18.1 & 13.85 & 11.05 & 10.64 \\
\hline 09 & 21.17 & 15.97 & 12.85 & 12.41 \\
\hline \multicolumn{5}{|c|}{ São Paulo } \\
\hline MANAGEMENTS & Stage 1 & StAge 2 & Stage 3 & Stage 4 \\
\hline 01 & 18.85 & 16.27 & 14.95 & 15.16 \\
\hline 02 & 12.76 & 12.63 & 15.73 & 17.76 \\
\hline 03 & 17.51 & 15.7 & 15.74 & 16.54 \\
\hline 04 & 17.52 & 13.61 & 12.04 & 12.15 \\
\hline 05 & 18.25 & 18.14 & 19.12 & 20.17 \\
\hline 06 & 16.62 & 13 & 11.88 & 12.63 \\
\hline 07 & 17.53 & 14.18 & 13.11 & 13.81 \\
\hline 08 & 15.47 & 12.59 & 12.11 & 13.17 \\
\hline 09 & 15.88 & 12.14 & 10.3 & 10.48 \\
\hline 10 & 15.47 & 12.59 & 12.11 & 13.17 \\
\hline
\end{tabular}

Figure 6: Distance between phases genetically pure Source: Research data

After submitting the responses of managers to the calculus of its distance in relation to each of the reference phases described by Bates et al (1995) was prepared the Figure 7. The calculations were obtained by a membership function given by the expression:

$\left.\mathrm{p}=1-\left(\underline{\mathrm{d}\left(e_{\mathrm{i}}\right.} \underline{e}_{\mathrm{i}}\right)\right)$, where:

$$
21,5
$$

$\mathrm{p}=$ pertinence

$\mathrm{d}=$ distance

$e_{\mathrm{i}}=$ alleles diffuse

$e_{\mathrm{j}}=$ alleles reference

21,5 = great estimated distance between the data (Figure 6)

Figure 7 presents the classification of diffuse of all the responses of managers per unit. The answers are seen belonging to some degree to the stages.

\begin{tabular}{|c|c|c|c|c|c|}
\hline \multicolumn{6}{|c|}{ Golás } \\
\hline 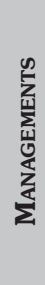 & 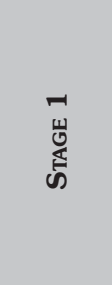 & $\begin{array}{l}N \\
w \\
\frac{U}{5} \\
\dot{E} \\
\omega\end{array}$ & 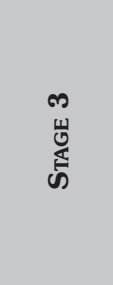 & $\begin{array}{l}+ \\
\text { யँ } \\
\overleftarrow{5} \\
\omega\end{array}$ & 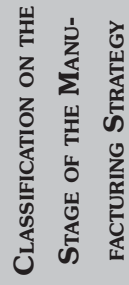 \\
\hline 01 & $5.93 \%$ & $23.49 \%$ & $34.18 \%$ & $36.40 \%$ & Stage 4 \\
\hline 02 & $10.24 \%$ & $29.48 \%$ & $31.99 \%$ & $28.29 \%$ & Stage 3 \\
\hline 03 & $14.84 \%$ & $25.90 \%$ & $29.98 \%$ & $29.28 \%$ & Stage 3 \\
\hline \multicolumn{6}{|c|}{ Rio Grande do Sul } \\
\hline 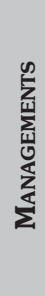 & $\begin{array}{l}-1 \\
\text { 岁 } \\
\text { के }\end{array}$ & 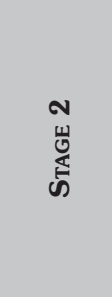 & 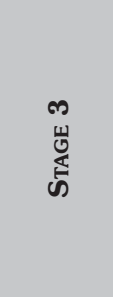 & 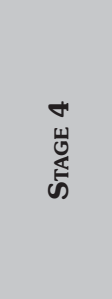 & 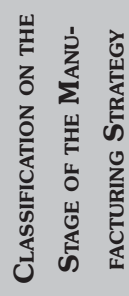 \\
\hline 01 & $16.96 \%$ & $27.83 \%$ & $29.14 \%$ & $26.07 \%$ & Stage 3 \\
\hline 02 & $9.97 \%$ & $24.21 \%$ & $32.25 \%$ & $33.57 \%$ & Stage 4 \\
\hline 03 & $7.15 \%$ & $24.66 \%$ & $33.88 \%$ & $34.31 \%$ & Stage 4 \\
\hline 04 & $16 \%$ & $28.34 \%$ & $29.30 \%$ & $26.36 \%$ & Stage 3 \\
\hline 05 & $3.56 \%$ & $25.03 \%$ & $35.53 \%$ & $35.88 \%$ & Stage 4 \\
\hline 06 & $9.78 \%$ & $24 \%$ & $32.33 \%$ & $33.89 \%$ & Stage 4 \\
\hline 07 & $1.49 \%$ & $23.86 \%$ & $36.66 \%$ & $38 \%$ & Stage 4 \\
\hline
\end{tabular}




\begin{tabular}{|c|c|c|c|c|c|}
\hline 08 & $10.51 \%$ & $23.64 \%$ & $32.29 \%$ & $33.56 \%$ & Stage 4 \\
\hline 09 & $1.40 \%$ & $23.43 \%$ & $36.65 \%$ & $38.52 \%$ & Stage 4 \\
\hline \multicolumn{6}{|c|}{ São Paulo } \\
\hline 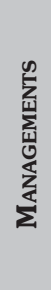 & 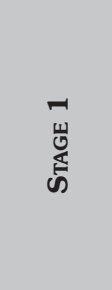 & $\begin{array}{l}\text { N } \\
\text { Uू } \\
\text { है } \\
\text { के }\end{array}$ & 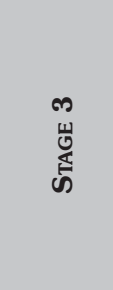 & 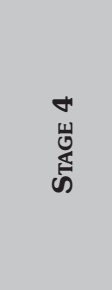 & 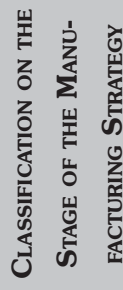 \\
\hline 01 & $11.45 \%$ & $25.20 \%$ & $32.23 \%$ & $31.11 \%$ & Stage 3 \\
\hline 02 & $32.80 \%$ & $33.32 \%$ & $20.98 \%$ & $12.90 \%$ & Stage 2 \\
\hline 03 & $18.85 \%$ & $28.63 \%$ & $28.42 \%$ & $24.10 \%$ & Stage 2 \\
\hline 04 & $12.13 \%$ & $25.77 \%$ & $31.24 \%$ & $30.86 \%$ & Stage 3 \\
\hline 05 & $33.05 \%$ & $34.38 \%$ & $22.60 \%$ & $9.98 \%$ & Stage 2 \\
\hline 06 & $14.66 \%$ & $26.78 \%$ & $30.53 \%$ & $28.02 \%$ & Stage 3 \\
\hline 07 & $13.68 \%$ & $26.88 \%$ & $31.10 \%$ & $28.34 \%$ & Stage 3 \\
\hline 08 & $18.04 \%$ & $27.43 \%$ & $29 \%$ & $25.54 \%$ & Stage 3 \\
\hline 09 & $14.55 \%$ & $25.17 \%$ & $30.40 \%$ & $29.89 \%$ & Stage 3 \\
\hline 10 & $18.04 \%$ & $27.43 \%$ & $29 \%$ & $25.54 \%$ & Stage 3 \\
\hline
\end{tabular}

Figure 7: Diffuse classification stages in the framework of manufacturing strategy

Source: Research data

\subsection{Analysis of Unit Goiás}

The analysis unit notes that the Unit of Goiás between the three managing respondents, the responses of two managers classify the unit at Stage 3 (31.99\% and $29.98 \%$ ) and a management at Stage 4 (36.4\%). "That is, the unit is in Stage 3 of the manufacturing strategy, but also taking into account the characteristics belonging to Stage 4. In Stage 3 the company develops support for its business strategy". (HAYES; WHEELWRIGHT, 1984, p. 396)

On the Phases 5, 6, 7, 8 (referred in the Construct - Figure 1) by means of averages (scale from 1 to 5 ) of these phases has been in the Unit of Goiás, a higher score on Phase 6 - Force Strategy Production (4.92), followed by Phases 7 - Formal Strategic Planning (4.83) and 8 - Communication Strategies (4.17) and a lower score on Stage 5 - Long-Term Orientation (2.93).

\subsection{Analysis of Unit Rio Grande do Sul}

In Unit of Rio Grande do Sul, the responses of two managers classify the unit at Stage $3(29.14 \%$ and $29.30 \%$ ) and the responses of seven managers rate the unit at Stage 4 (33.57\%; 34.31\% 35.88\% 33.89\%, $38 \%, 33.56 \%, 38.52 \%$ ). That is, the unit is in Stage 4 of the manufacturing strategy, but with some features still in Stage 3. In Stage 4 "[...] the company pursues a basis of competitive advantage from the manufacturing and creates a standard that will be sought by other companies" (HAYES; WHEELWRIGHT, 1984, p. 396). On the Phases 5, 6, 7, 8 through the medium, it will be based in Rio Grande do Sul, a higher score on Phase 6 (4.69), followed by Phase 8 (4.14) and 7 ( 4.11) and with a lower score in Stage 5 (2.93).

\subsection{Analysis of Unit of São Paulo}

In the Unit of São Paulo, the responses of three managers rate the unit at Stage 2 (33.32\%, 28.63\%, $34.38 \%$ ) and the responses of seven managers classified in Stage 3 (32.23\%; 31.24\%, 30.53\%, 31.10\%, $29 \%, 30.4 \%$ and 29\%). That is, the unit is in Stage 3 of the manufacturing strategy, but with some features still in Stage 2.

On the Phases 5, 6, 7, 8 through the medium of the average, it will be based in São Paulo, a higher score on Phase 6 (4.58), followed by Phase 8 (4.38), 7 (4.05) and with a lower score in Phase 5 (3.18). These phases to the ranking was the same as the unit of Rio Grande do Sul.

\subsection{Analysis of Phases Characterizing the Strategy-as-Practice}

With respect to Phases that present activities that the strategy-as-practice, after selecting the phases (among those listed in Construct - Figure 1), it stood out among those who have received above average, 4 out of four-point of Likert Scale (since they have agreed partially or totally). 


\begin{tabular}{|c|c|c|c|c|}
\hline \multicolumn{5}{|c|}{ Average Score } \\
\hline $\begin{array}{c}\text { Phases that have } \\
\text { ACtivities THAT CHARAC- } \\
\text { TERIZE THE STRATEGY-AS- } \\
\text {-PRACTICE }\end{array}$ & GO & RS & SP & $\begin{array}{l}\text { HighLI- } \\
\text { GHTED IN } \\
\text { UNITS }\end{array}$ \\
\hline 1.1 Control Systems & 5 & 5 & 4.7 & $\begin{array}{l}\text { GO, RS, } \\
\text { SP }\end{array}$ \\
\hline 2.1 Industrial Practices & 5 & 4.6 & 3.6 & GO, RS \\
\hline $\begin{array}{l}2.4 \text { Planning based in } \\
\text { the repetition of the } \\
\text { tasks }\end{array}$ & 2 & 3.8 & 2.7 & - \\
\hline $\begin{array}{l}3.1 \text { Systematic } \\
\text { Production }\end{array}$ & 3.3 & 4.6 & 3.8 & RS \\
\hline $\begin{array}{l}3.2 \text { Continuity in the } \\
\text { strategy of production }\end{array}$ & 4 & 4.4 & 4.4 & $\begin{array}{l}\text { GO, RS, } \\
\text { SP }\end{array}$ \\
\hline $\begin{array}{l}\text { 3.3 Business strategy } \\
\text { involving the production }\end{array}$ & 4.3 & 4.6 & 4 & $\begin{array}{l}\mathrm{GO}, \mathrm{RS} \\
\mathrm{SP}\end{array}$ \\
\hline $\begin{array}{l}3.4 \text { Investments in } \\
\text { production as business } \\
\text { strategy }\end{array}$ & 3.7 & 4.4 & 4.4 & $\mathrm{RS}, \mathrm{SP}$ \\
\hline $\begin{array}{l}\text { 3.5 Production in line } \\
\text { with the strategy }\end{array}$ & 4.7 & 4.8 & 4.3 & $\begin{array}{l}\mathrm{GO}, \mathrm{RS} \\
\mathrm{SP}\end{array}$ \\
\hline $\begin{array}{l}\text { 4.1 Development of } \\
\text { own equipment }\end{array}$ & 4.7 & 4.2 & 3.8 & $\mathrm{GO}, \mathrm{RS}$ \\
\hline $\begin{array}{l}4.2 \text { Area and production } \\
\text { involved with decisions }\end{array}$ & 4 & 4.7 & 2.9 & $\mathrm{GO}, \mathrm{RS}$ \\
\hline 4.4 Long-term programs & 4 & 4.9 & 4.4 & $\begin{array}{l}\mathrm{GO}, \mathrm{RS} \\
\mathrm{SP}\end{array}$ \\
\hline $\begin{array}{l}\text { 4.5 Anticipation of new } \\
\text { production processes }\end{array}$ & 5 & 4.7 & 4.2 & $\begin{array}{l}\mathrm{GO}, \mathrm{RS} \\
\mathrm{SP}\end{array}$ \\
\hline $\begin{array}{l}5.4 \text { Long-term } \\
\text { orientation }\end{array}$ & 2.3 & 4.3 & 3.1 & $\mathrm{RS}$ \\
\hline $\begin{array}{l}6.2 \text { Developed } \\
\text { production strategy }\end{array}$ & 5 & 4.8 & 4.5 & $\begin{array}{l}\mathrm{GO}, \mathrm{RS} \\
\mathrm{SP}\end{array}$ \\
\hline $\begin{array}{l}\text { 6.3 Production with } \\
\text { focus }\end{array}$ & 4.7 & 4.7 & 4.7 & $\begin{array}{l}\mathrm{GO}, \mathrm{RS} \\
\mathrm{SP}\end{array}$ \\
\hline $\begin{array}{l}\text { 6.4 Production with } \\
\text { competitive strength }\end{array}$ & 5 & 4.7 & 4.6 & $\begin{array}{l}\mathrm{GO}, \mathrm{RS} \\
\mathrm{SP}\end{array}$ \\
\hline $\begin{array}{l}8.1 \text { Communication } \\
\text { strategy to all }\end{array}$ & 4.7 & 4.7 & 4.7 & $\begin{array}{l}\mathrm{GO}, \mathrm{RS} \\
\mathrm{SP}\end{array}$ \\
\hline $\begin{array}{l}8.2 \text { Communication } \\
\text { strategy to managers }\end{array}$ & 2.7 & 2 & 3.5 & - \\
\hline $\begin{array}{l}8.3 \text { People familiar with } \\
\text { the planning }\end{array}$ & 5 & 4.9 & 4.5 & $\begin{array}{l}\text { GO, RS, } \\
\text { SP }\end{array}$ \\
\hline
\end{tabular}

Figure 8: Phase presenting activities that characterize the strategy-as-practice

Source: Research data
We can see that the unit of Rio Grande do Sul, there are the same phases that stood out in the Unit of Goiás and the activities of Phases 3.1 - Production Systematic; 3.4 - Investments in production as a business strategy; 5.4 - Orientation long term. That is, the units of Rio Grande do Sul and Goiás have a similarity in most of the phases that characterize the strategy-as-practice.

The unit of Rio Grande do Sul has a higher number of phases highlighted (17) and the unit of São Paulo has a smaller number of phases highlighted (12).

\subsection{Linkage between the Phases that characterize Strategy-as-Practice with the Stages of Manufacturing Strategy}

By analyzing the results, it is considered that on the stage of manufacturing strategy, the Unit of Goiás is in Stage 3, but also taking into account the characteristics belonging to Stage 4. The Unit of Rio Grande do Sul is in Stage 4, but with some features still in Stage 3. The Unit of São Paulo is in Stage 3, but with some features still in Stage 2. Unit of Rio Grande do Sul is the most advanced Stage, followed by the Unit of Goiás, and this, followed by the Unit of São Paulo.

Phase 6 - Strength Strategy Production highlights in the three units with the highest score. With respect to the Phases presenting activities hat the strategy-as-practice, the Units of Rio Grande do Sul and Goiás have a similarity in most phases, as shown in Figure 8.

Comparing the phases that characterize the strategy-as-pratice with the Stages of Manufacturing Strategy, the Unit of Goiás (is in Stage 3, but also taking account of characteristics belonging to Stage 4) and the Unit of Rio Grande do Sul (is in the Stage 4) seem to indicate a relationship between the highest average in phases that characterize the strategy-as-practice with the Stage in which the units are. That is, the more phases that characterize the strategy-as-practice have higher score, the more they are contributing to the to meet the highest level of the stages of manufacturing strategy.

As with the unit of Rio Grande do Sul which has a larger number of phases that characterize the strategy-as-practice and is in Stage 4. At this stage according to Hayes and Wheelwright (1984, p. 396) "[...] the company pursues a basis of competitive advantage 
from the manufacturing and creates a standard that will be sought by other companies". Also as mentioned by Hayes and Wheelwright (1984) the area of operations will take an important role within the company's competitive strategy.

\section{Final Considerations}

This study aimed at analyzing at what stage of the manufacturing strategy drives the organization are in accordance with the adaptation of Model Bates et al. (1995). And also consider what phases present activities that characterize the strategy-as-practice.

To achieve these goals developed two guiding questions for research. Regarding the first question At what stage of the manufacturing strategy business units are adapted according to the Model of Bates et al. (1995)? The Unit of Goiás is in Stage 3 (developing support for your business strategy), but also taking account of characteristics belonging to Stage 4 (pursuing competitive advantage from the manufacturing and creates a standard to be followed by other companies). Unit of Rio Grande do Sul is in Stage 4, but with some features still in Stage 3. The Unit of São Paulo is in Stage 3, but with some features still in Stage 2. Standing out as a unit of Rio Grande do Sul.

For the second main question - What are the phases that have activities that characterize the strategy-as- practice? The phases outlined are: control systems; industrial practice; systematic production; continuity of production strategy; business strategy involving the production; investment in production as business strategy; production in line with the strategy; development of own equipment; area involved in production decisions; long-term programs; anticipation of new production processes; guidance of long-term; production strategy developed; production-focused; competitive force production; communication strategy at all and people familiar with the planning.

By analyzing the results, it is considered that a relationship exists between the highest average in Phases presenting activities that characterize the strategy-as-practice with the Stage of manufacturing strategy in which the units are. Units of Rio Grande do Sul and Goiás have a similarity in the results analyzed.
The limitations of this study highlight the potential bias of respondents as the sample size refers to different units belonging to the same organization. Moreover, the convenience sample does not allow generalization of results.

For future research, it is suggested to carry out a longitudinal study with the objective of verifying any change in position on the stage of the manufacturing strategies of the units. Also notice the need for further studies in manufacturing organizations by linking with the perspective of the strategy-as-practice. As the scholarship, mentions the use of the Model Bates et al. (1995) even if it is adapted. Finally, the analysis generated by this research will serve to reevaluate the company issues related to manufacturing strategy.

\section{RefERENCES}

BATES, K. A. et al. The Crucial Interrelationship Between Manufacturing Strategy and Organizational Culture. J. STOR Management Sciense, Philadelphia, v. 41, n. 10, p. 1.565-1.580, Oct. 1995.

BALOGUN, J.; JOHNSON, G. Organizational restructuring and middle manager sensemaking.

Academy of Management Journal, New York, v. 47, p. 523-549, 2004.

CORREA, H. L.; CORREA, C. A. Administração de produção e operações: manufatura e serviços uma abordagem estratégica. São Paulo: Atlas, 2004.

DRUCKER, P. F. Novos padrões para as organizações de hoje. Coleção Harvard de Administração. São Paulo: Editora Nova Cultural, 1986.

\section{FLOYD, S.W.; WOOLDRIDGE, B. Building strategy}

from the middle: reconceptualizing strategy process. London: Sage, 2000.

JARZABKOWSKI, P. Strategic practices: an activity theory perspective on continuity and change. Journal of Management Studies, Massachusetts, v. 40, n 1, p. 23-55, 2003.

$$
\text { Shaping strategy as a structuration process. }
$$

Academy of Management Journal, New York, v. 51, n. 4, p. 621-650, 2008. 
JARZABKOWSKI, P.; BALOGUM, J.; SEIDL, D. B. Strategizing - the challenges of a practice perspective. Human Relations, Los Angeles, v. 60, p. 5-27, 2007.

JARZABKOWSKI, P.; FENTON, E. Strategizing and organizing in pluralistic contexts. Long Range Planning, Wien, v. 39, p. 631-648, 2006.

JARZABKOWSKI, P.; SEIDL, D. The role of meetings in the social practice of strategy. Organization Studies, London, v. 29, n. 11, p. 1.391-1.426, 2008.

JARZABKOWSKI, P.; SILLINCE, J. A rhetoric-in-context approach to building commitment to multiple strategic goals. Organization Studies, London, v. 28, n. 11, p. 1.639-1.665, 2006.

JARZABKOWSKI, P.; WHITTINGTON, R. Directions for a troubled discipline: strategy research, teaching, and practice-introduction to the dialog. Journal of Management Inquiry, v. 17, n. 4, p. 266-268, 2007. JARZABKOWSKI, P.; WHITTINGTON, R. A strategy-aspractice approach to strategy research and education. Journal of Management Inquiry, London, v. 17, n. 4, p. 282-286, 2008.

HAIR, Jr. J. F. et al. Fundamentos de métodos de pesquisa em administração. Porto Alegre: Bookman, 2005.

HAYES, R. H.; WHEELWRIGHT, S. C. Restoring our competitive edge: competing through manufacturing. John Wiley and Sons, Inc. New York, 1984.

HEIN, N. Um modelo didático de otimização genética. In. BOLETIM do Departamento de Matemática da FURB, n 32, Blumenau, 1995.

HEIN, N.; Novello, A. A. Sistema classificador genético difuso do ciclo de vida das organizações. Anais... $6^{\circ}$ Congresso USP de Controladoria e Contabilidade, São Paulo, 2006.

HOLLAND, J. Adaptation in natural and artificial systems. Ann Arbor: The University of Michigan Press, 1975.

PAIVA, E. L. et al. Estratégia de produção e operações. Porto Alegre: Bookman, 2004.
REGNER, P. Strategy-as-practice and dynamic capabilities: steps towards a dynamic view of strategy. Human

Relations, Los Angeles, v. 6, p. 565-588, 2008.

RICHARDSON, R. et al. Pesquisa social: métodos e técnicas. São Paulo: Atlas, 1999.

ROULEAU, L. Micro-practices of strategic sensemaking and sensegiving: how middle managers interpret and sell change every day. Journal of Management Studies, Massachusetts, v. 42, p. 1.413-1.441, 2005.

SILVEIRA, A. et al. Roteiro básico para apresentação e editoração de teses, dissertações e monografias. 3. ed. Blumenau: Edifurb, 2009.

\section{SLACK, N. Vantagem competitiva em manufatura:} atingindo competitividade nas operações industriais. 2 . ed. São Paulo: Atlas, 2002.

SLACK, N. et al. Administração da produção. São Paulo: Atlas, 1997.

UYTERHOEN, H. E. R. Os gerentes sob pressão.

Coleção Harvard de Administração. São Paulo: Nova Cultural, 1986.

ZADEH, L. Fuzzy sets: information and control. 8, New York: EDITORA??, 1965.

WHITTINGTON, R. Completing the practice turn in strategy research. Organization Studies, London, v. 27, n. 5, p. 613-634, 2006. 